\title{
Adorno and Performance
}

Mischa Twitchin

UNCANNY IN MIMESIS (2015)

THE

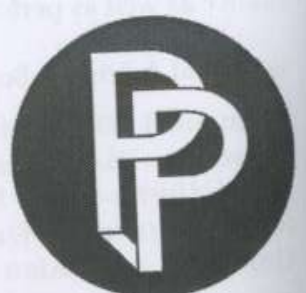

PERFORMANCE PHILOSOPHY

Published in association with the research network Performance Philosophy www.performancephilosophy.ning.com

Performance Philosophy

Series Standing Order ISBN 978-1-137-40739-9 (hardback)

978-1-137-40740-5 (paperback)

(outside North America only)

You can receive future titles in this series as they are published by placing a stand-

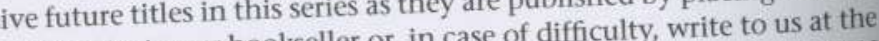
ing order. Please contact your bookseller or, in case of difteries and the ISBN and your name and address, quoted above.

Department, Macmillan Distribution Ltd, Houndmills, Basingstoke, Hampshire RG21 6XS, England.

\section{Edited by}

Will Daddario

Assistant Professor in Theatre Studies, Illinois State University, USA

and

Karoline Gritzner

Lecturer in Drama and Theatre Studies, Aberystwyth University, UK

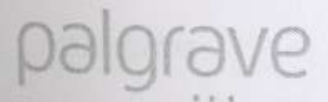

macmillan 
All rights reserved. No reproduction, copy or transmission of this publication may be made without written permission.

No portion of this publication may be reproduced, copied or transmitted save with written permission or in accordance with the provions of the save with written perigns and Patents Act 1988, or under the terms of any Copyright, Designs and Patents Act 1988, Copyright Licensing Agency, permitting limited copy Street, London EC1N 8TS.

Saffron House, 6-10 Kirby Street, Lofication Any person who does any unauthorize act in relaims for damages.

may be liable to criminal prosecution and civil claims for damages. The authors have asserted their rights to be identified as the authors 1988. work in accordance with the Copyright, Designs

\section{First published 2014 by}

PAIGRAVE MACMILLAN

U UK is an imprint of Macmillan Publishers Limited, ristered in England, company number 785998, of Houndmills, Basingstoke, Hampshire RG21 6XS.

Palgrave Macmillan in the US is a division of St Martin's Press LLC, 175 Fifth Avenue, New York, NY 10010.

Pacmillan is the global academic imprint of the above companies Palgravas companies and representatives throughout the world.

Palgrave ${ }^{\oplus}$ and Macmillan ${ }^{\circledast}$ are registered trademarks in the United States, the United Kingdom, Europe and other countries.

ISBN 978-1-137-42987-2

This book is printed on paper suitable for recycling and made from fully managed and sustained forest sources. Logging, pulping and manufacturing prected to conform to the environmental regulations of the country of origin.

A catalogue record for this book is available from the British Library.

Library of Congress Cataloging-in-Publication Data

Adorno and performance / Will Daddario, Karoline Gritzner [editors].

pages cm.- (Performance philosophy)

Includes bibliographical references and index

ISBN 978-1-137-42987-2

Theater-Philosophy, 2. Performing arts-Philosophy. 3. Adorno, 1. Theater editor.

PN2039.A38 2014

$791.01-\mathrm{dc} 23$

Typeset by MPS Limited, Chennai, India. 


\section{Contents}

Series Preface

Acknowledgments

Notes on Contributors

Introduction to Adorno and Performance

Will Daddario and Karoline Gritzner

1 Of Adorno's Beckett

Michal Kobialka

2 Thoughts Which Do Not Understand Themselves:

On Adorno's Dream Notes

Karoline Gritzner

3 Performativization and the Rescue of Aesthetic Semblance Andrea Sakoparnig

4 On the "Difference between Preaching an Ideal and Giving Artistic Form to the Historical Tension Inherent in It" Mischa Twitchin

5 Cooking up a Theory of Performing Anthony Gritten

6 Thinking Performance in Neoliberal Times: Adorno Encounters Neutral Hero Ioana Jucan

7 Pleasing Shapes and Other Devilry: An Adornian Investigation of La Pocha Nostra Praxis Stephen Robins

8 Thinking - Mimesis - Pre-Imitation: Notes on Art, Philosophy, and Theatre in Adorno's Aesthetic Theory Marcus Quent

9 On the Theatricality of Art Anja Nowak

10 Adorno and Performance: Thinking with the Movement of Language Birgit Hofstaetter 
11 What Is Adorno Doing? Immanent Critique as Philosophical Performance Mattias Martinson

12 The Vanity of Happiness: Adorno and Self-Performance Julie Kuhlken

13 Writing as Life Performed Martin Parker Dixon

Bibliography

\section{Series Preface} will embrace philosophical approaches from those working within any discipline or definition of performance, including but not limited to, theater, dance, music, visual art, performance art and performativity in everyday life.

In turn, the series aims to both sharpen and problematize the definition of the terms "performance" and "philosophy," by addressing the relationship between them in multiple ways. It is thus designed to support the field's ongoing articulation of its identity, parameters, key questions and core concerns; its quest is to stage and re-stage the boundaries of Performance Philosophy as a field, both implicitly and explicitly. The series also aims to showcase the diversity of interdisciplinary and international research, exploring the relationship between performance and philosophy (in order to say: "This is Performance Philosophy."), whilst also providing a platform for the self-definition and self-interrogation of Performance Philosophy as a field (in order to ask and ask again: "What is Performance Philosophy?" and "What might Performance Philosophy become?"). That is to say, what counts as Performance Philosophy must be ceaselessly subject to redefinition in the work of performance philosophers as it unfolds.

But this does not mean that "anything goes" or that the field of Performance Philosophy is a limitless free-for-all. Rather, both the field and this series specifically bring together all those scholars for whom the question of the relationship between performance and philosophy and, therefore, the nature of both performance and philosophy (including their definitions, but also their "ontology" or "essential conditions"), are of primary concern. However, in order to maintain its experimental and radical nature, Performance Philosophy must also be open to including those scholars who may challenge extant concepts of "performance" 
recognized the epistemic quality of performance. As we have seen, he saw it as the epitome of an operation that confirmed the illusory nature of aesthetic semblance. Moreover, Adorno was, from the very beginning, completely aware of the importance of the active involvement of the seemingly passive recipient. More than any other theorist, he linked aesthetic objectivity to the re-enactment and reflection of the participant - characteristics that were only placed in the foreground later by theorists of performance studies (such as Fischer-Lichte, for example).

Perhaps it is stating the obvious to assert that Adorno contributes some really important ideas to aesthetics. Through him, we arrive at an understanding of the artwork as a highly critical entity. His ideas on the antinomies of objectifications and the reflective quality of the performance dimension have the potential to enrich virtually all of our conceptualizations in performance studies so far.

\section{On the "Difference between Preaching an Ideal and Giving Artistic Form to the Historical Tension Inherent in It"}

\author{
Mischa Twitchin
}

This difference, concerning an ideal (which also suggests the potential of and for a political theatre), is noted by Adorno in the course of an essay that seeks to rescue the notion of Goethe's "classicism" from its received tradition (not least, by saving questions of form and art from those of "style" and "culture"). ${ }^{1}$ Following an analysis already proposed in the Dialectic of Enlightenment (1944), an "affirmative" reading of the relation between reason and sacrifice (or between law and power) is critically addressed here through the example of Goethe's play Iphigenia in Tauris. ${ }^{2}$ This play is traditionally seen to reconcile the very antinomies that constitute its drama - between the humane and the barbaric, enlightenment and myth, reason and nature - through the "progressive" repression of the second value by the first; a tradition that makes of the play, indeed, the "preaching of an ideal." ${ }^{3}$ Adorno's reading, by contrast, seeks to draw out the historical tensions to which the question of aesthetic form testifies, which itself raises a question as to the reading of Adorno.

His exploration of the humane in Iphigenia, for example, is partly oriented by the critical observation that, "the one to whom the work entrusts the voice of utopia is also the one it denigrates as insane" (Adorno, "Goethe's Iphigenia" (1967) 167). While the question of this "voice" concerns Orestes' visions in Act 3 specifically, it finds a curious echo in a later remark (made in a letter to Herbert Marcuse) concerning student politics in 1969 , about which Adorno writes:

I am the last to underestimate the merits of the student movement: it has interrupted the smooth transition to the totally administered world. But it is mixed with a dram of madness, in which 
the totalitarian resides teleologically, and not at all simply as a repercussion (though it is this too). ("Correspondence" 136)

Here the troubled relation between interpretation and praxis is itself troubling, where dialectics, however critical, seems hardly immune from the danger of becoming didactic. ${ }^{4}$

The relation between autonomy and heteronomy - as between claims concerning subjective and objective conditions of experience (not least for effecting their change) - resonates in Adorno with the particularity of a twentieth-century understanding of a "damaged life." In the relation between theory and praxis, a question of philosophical form is posed in the possibility of a critical distance that is traditionally conceived in relation to theatre or performance (as distinct, for instance, from a demonstration or a riot). Both critical thought and artistic form are engaged in the tension between the utopian and the historical as figures for past and future possibilities of the present. What might an identification of the utopian with madness mean, then, for contemporary appeals to what appears as a "classical" ideal of autonomy, beyond the "human rights" that have come to define the narrative of a "progressive" history (in which society is identified with the state)?

The irreconcilability of self-consciousness with the knowledge of its historical (political-economic) conditions of possibility is, after all, its very defence against the insanity to which it would otherwise be condemned by the masquerade of power as "reality." Indeed, could the relation between violence and resistance ever be reconcilable in a relation between theory and practice (or, as we might say, between philosophy and performance) - where it is precisely this resistance that makes these relations dynamic? As a dialectical tension, articulated in the thought of artistic form (or even as "performance philosophy"), how has this resistance been manifested historically in the example of Iphigenia?

Within twentieth-century "humanities," the play's antinomies are erhaps exemplified by the contrasting memories of its drama expressed by the principal characters in Imre Kertesz's novella The Pathseeker, a contrast that can be condensed in terms of the - ostensibly opposed place names of Weimar and Buchenwald (Pathseeker 83-87). Here the relation between the utopian and the insane is as unsettling as the journey between these two sites - ideal and historical - of cultural memory. Traditionally, an ideal of the humane (as characterised by the dialogue between consciousness and conscience) offers an alibi for the historical knowledge of inhumanity, even where an identification of law and power presents itself in its utterly political violence. ${ }^{6}$ This is not a question - for Kertesz - of what remains of the humanities (of Weimar classicism, for instance) after Buchenwald, as if the past could be split off from the present (any more than from its future). Rather, it is a question of what returns in the example of Iphigenia - in the medium of artistic form - as a possibility of the relation between performance and philosophy within cultural memory.

The ideal of the "magnanimity of power" (as an arbitrary, or repressive, reconciliation of antinomies), to which readings of Iphigenia have traditionally conformed, is itself an insane invitation to identify with the "reality" of power, as if this "reality" were historically inevitable and not subject to change, least of all in the name of (if not by) its victims. Indeed, the claim that "there is no alternative" remains one of the most pernicious - and pervasive - claims of contemporary political economy in a supposed legitimation of state violence. How then might aesthetic form admit the ("humane") voice of its own reason as art (whether as theory in practice or as philosophy in performance) in the example of Iphigenia? In what follows, this question will be addressed in three, contrasting instances from the late 1960s, with Rainer Werner Fassbinder, Joseph Beuys, and Adorno.

\subsection{Rainer Werner Fassbinder}

In 1968, Rainer Werner Fassbinder offered an "anti-theatrical" view of Goethe's play under the title of Iphigenia on Tauris by Johann Wolfgang von Goethe - in which, as David Barnett notes, the "inclusion of Goethe's authorial name already sets up an attack on such authority in the writing by contextualising the object of criticism: Goethe and his bourgeois humanism" (Rainer Werner Fassbinder 88). Not the least of the paradoxes in Fassbinder's heavily cut version of the play - underpinning a textual montage that also includes Mao and contemporary West German court proceedings - is its very dependence upon the humanistic reading that it opposes. By externalising the antinomies to which it wants to bear witness, Fassbinder aims (like the tradition) to make a virtue of "preaching an ideal" (albeit inverted).

Concerning the education of power by the example of reason, Fassbinder's critique is condensed in the reflection, given to Arkas, a servant of the barbarian king, Thoas: "In Rainer Werner Fassbinder's school exercise book, it says Iphigenia on Tauris is a drama about the magnanimity of the mighty. Neues Realgymnasium, 1962" (Barnett, Rainer Werner Fassbinder 86$).^{8}$ The play's rewriting attempts to perform didactically the irreconcilability of enlightenment with barbarism, 
reproducing the very form of authority that it is quoting. Indeed, the play thereby attempts to stage the irreconcilability of enlightenment with itself, through that of the characters with their own speeches, providing a model for that of the audience with the tradition to which the performance simultaneously appeals.

However, as Adorno points out, Goethe's play already articulates the hope of and for an alternative to the "necessity" of tragedy through the very paradoxes of its human appeal to reason (distinct from the arbitrary deliverance provided by a deus ex machina, as in Euripides). ${ }^{9}$ The condition for the liberation of Iphigenia and Orestes from their family curse (as the grandchildren of Atreus), and from the rites of the sacrifice of strangers in Taurus, is the recognition of an "enlightened barbarian." This acknowledgment of the Other's "humanity" (whether in nature, myth, or madness), as the condition of the subject's freedom, already troubles idealist claims to the universal - in which the possibility of an "enlightened enlightenment" remains, indeed, utopian. ${ }^{10}$

A year after the initial success of his play, Fassbinder sat in the audience for a very different performance interpretation - at the same theatre that he would later become artistic director of, the Theater am Turm in Frankfurt. Invited by Claus Peymann (the then director of the TAT) to design a production for the 1969 Frankfurt Experimenta festival, Joseph Beuys had instead offered to perform his "favourite play" himself. ${ }^{1}$

\subsection{Joseph Beuys}

The extraordinary images - or what Beuys evocatively called "radiographs" - of this performance (given only twice, on 29 and 30 May, with the second evening cut short owing to aggressive audience interventions) were the subject of a recent exhibition (shown in Munich, 2011, and then Paris, 2012), in which a potential relation between performance and philosophy appears as an inscription of time in artistic form. This appearance concerns not simply what of an event is remembered but how, where the mode of existence by which the performance may be conceived of, in - and as - its afterlife, is not only photographic, but also literary. ${ }^{12}$

How this ("radiographic") possibility of time (as "performance art") enters into its - ostensibly - opposed condition (as "exhibition art") is not least a question for philosophical, or critical, aesthetics. In this case, the exhibition's curator, Jörg Schellmann, declares his own interest, proposing that: "Pictures should ideally reflect the time in which we live and when they were created: a record of art in its time" (Schellmann, Forty 8 ). Here, however, we are concerned with the difference between the time in which we live and the time when the images were created; that is, with the time that these artistic images have themselves created. Indeed, the thought of the performance image - as having been "burnt into our memory" [Die Bilder haben sich in unsere Erinnerung eingebrannt...] - with which Schellmann introduces the Iphigenia exhibition (acknowledging the distance of "over forty years" that their light has traveled) implicitly cites a literary appeal to its afterimage made by Peter Handke at the time (Schellmann, Joseph Beuys 5). ${ }^{13}$

This eye-witness testimony (originally published in the Frankfurter Allgemeine Zeitung, 13 June 1969, a fortnight after Beuys' performance) concludes with the following thoughts:

But the further this event recedes in time, the less important do these digressions become [referring to Beuys being occasionally distracted by the audience], and the more strongly do the horse and the man moving on stage and the voices over the loudspeakers merge into an image that one could call ideal. In the memory it seems to have been fused into one's own life, an image that works through both nostalgia and the will to produce such images oneself: for it is only as an afterimage that it really starts to work in one's own mind. ${ }^{14}$ And an excited state of stillness comes over me when I think of it: it activates me, it is so painfully beautiful that it becomes Utopian, and that means political. (cit. Tisdall, Joseph Beuys 182)

This ekphrasis, composing aesthetic experience in and as its afterimage (in which the utopian touches upon the political; not least because it is embodied), also appears clairvoyantly like an example for Adorno's suggestion (in Aesthetic Theory (1970)):

When stimuli are transposed into works of art, and by dint of the works' integrative capacity are assimilated into them, they remain, within the aesthetic continuum, tokens of an extra-linguistic naturealthough, as their after-images, they are no longer physically present. This ambivalence is registered in every genuinely aesthetic experience, and is incomparably expressed in Kant's description of the sense of the sublime as being something that trembles within itself between nature and freedom. (cit. Wiggershaus, Frankfurt School 651$)^{15}$

With this evocation of what there is in art that is not reducible to art, what might be the philosophical - because artistic - questions that 
attend Beuys' performance, at least in (or as) its afterimage? If all that can be known of the future is in the past, as its potential for interpretation (if it is not thereby changed), what returns in the afterimage of Beuys' performance, in the very "distance" it recalls? What is still "present" (but no longer physically) of "an extra-linguistic nature" in the light of an image that is burnt into memory? What appeals, beyond personal memory, to be given voice as "utopian" in the question of ambivalence between law and nature in this example of Iphigenia? What might be the appeal of a work of art - a "radiograph" - in so far as it resists the attempt to reduce the past to the present (as in the uncritical vogue for "re-enactment," supposed to legitimate the museum of "live art")? Is this evocation (or citation) of the aesthetic memory of historical time ("etched," "burnt into," "fused into") simply a figure of speech, a literary metaphor? Or is it a thoughtimage of what remains present (as "extra-linguistic") of performance in philosophy, of that which is not thinkable in its present? In what sense (that is not "insane") does this question (in and of the distance between performance and philosophy, action and interpretation) become political?

\subsection{Adorno}

But why do we not also ask such questions (about an event and its afterimage) of philosophy, with respect to Adorno's Iphigenia lecture, for instance? This was, after all, addressed to an audience at a particular time and place, and also aggressively interrupted. The relations between violence and reason, past and present, state power and individual will, concern what all these instances of an Iphigenia interpretation from the late 1960 s may still have to teach us, with respect to the relationship between philosophy and performance - not least as such interpretation concerns both university education and citizenship.

Invited by Peter Szondi, Adorno's lecture on "Goethe's classicism" was given at the Free University in Berlin, on 7 June 1967, only five days after the shooting by a policeman, Karl-Heinz Kurras, of a student, Benno Ohnesorg, during protests against a visit to the city by America's client-dictator, the Shah of Iran. Adorno refused a request to cancel his talk in favour of a political discussion (given the circumstances, as a proposed gesture of solidarity with the protesters) and his lecture was disrupted by students who unfurled banners in the auditorium declaring: "Iphigenists of the world unite!" and "Berlin's left-wing fascists greet Teddy the classicist" (Kraushaar, Frankfurter Schule 267). ${ }^{16}$
The protesters' epithet of "left-wing fascism" mocks a reference to the student movement current at the time, used most notoriously (and subsequently regretted) by Jürgen Habermas in reply to Rudi Dutschke at the conference on "University and Democracy: Conditions and Organisation of Opposition" which was held in Hanover on 9 June, following Ohnesorg's funeral there.

At least, this is what one would learn from Lorenz Jäger's biography of Adorno (Jäger, Adorno 198). One learns from Rolf Wiggershaus, however, that the lecture was given a month later - on 7 July - and, thanks to Szondi's public commitment against the prosecution of members of the Berlin "Commune One" at the time, passed off "more or less without interruption" (Wiggershaus, Frankfurt School 621). ${ }^{17}$ The point here is not Jäger's misplacing of the month but rather the reading that is given as a consequence. The parapractic performance (simpler in German, between Juni and Juli) consists not in a failure of editorial "fact checking" but in the truth of the implications concerning an ideal of "classicism" which it allows for - a truth, concerning a "historical tension," that precisely its falsity admits of. ${ }^{18}$

To read the subsequently printed lecture as if it were simply an instance of the "closed" literary object, beloved of those who would fillet out the historical tension from the question of artistic form, is to forestall the sense in which a reading might question its own conditions of interpretation. ${ }^{19}$ This applies to the example of Adorno's construction of Goethe (which discusses his "move to Weimar" precisely in its relation to the "dark secret of a [bourgeois] revolution"), as much as to Fassbinder or Beuys (Adorno, "Goethe's Iphigenia" 162). ${ }^{20}$ What, after all, could be supposed of Iphigenia as an ideal of Weimar "classicism" in a context in which the Springer press reported the police murder of Ohnesorg in terms of a legitimate assertion of "law and order," with the implied "necessity" - for the defence of the state - of a sacrificial politics? ${ }^{21}$ The voice of Adorno's own "classicism" may be read into what is artful in the lecture, considering the historical tensions that it appears not to address; specifically with respect to individual responsibility in the relation between state and violence, as this testifies to historical time.

The associations that Jäger offers for the post-war German context are rich in ironies. By the mid-1960s, for instance, the Dialectic of Enlightenment (a reprinting of which was continually deferred by its authors) had been liberated from the confines of the academic library and appeared as a call to arms - or at least as an appeal to passers-by to pause and reflect on the "economic miracle" - when a student group, 
calling itself Subversive Action, abstracted a sentence-length manifesto, which they distributed as a poster in several cities in May 1964:

The Culture Industry has succeeded in transforming subjects into social functions and done this so undifferentiatedly that those who are completely seized by this, no longer mindful of any conflict, enjoy their own dehumanisation as something human, as the happiness of warmth. (Jäger, Adorno 194-5)

This declaration was "signed" with Adorno's name and address - an action to which he took grave exception, especially when presented with a bill by the University of Stuttgart for removing the posters from its walls.

For those on the left, however, the feared "subversion" was from the proposal of the main political parties at this time to enact "emergency laws" protecting the privileges of the state from the extra-parliamentary opposition, of which the student movement was a key part. This attempt to amend the constitution (eventually passed in May 1968) was characterised by Jürgen Habermas, in the Frankfurt student magazine: "not so much that the safety of democracy will be ensured during the state of emergency as that a state of emergency will be imposed on democracy" (cit. Wiggershaus, Frankfurt School 598).

Where a "state of emergency," representing an extreme of the antinomies repressed by the "magnanimity of power," is today being enacted in fiscal terms in the name of "austerity," the concomitant questions (both hermeneutic and practical) concerning citizenship and public space, protest and education, the university and democracy remain as urgent as ever. ${ }^{22}$ The question of "resistance" (posed in the relation between performance and philosophy) concerns what of the humane may yet be sacrificed on the altar of power in the name of "necessity." The long march towards the privatisation of English universities, for instance, continues a consumerisation of citizenship in which a university's value (to remain "open" as a public space) becomes increasingly a matter of its commercial viability. ${ }^{23}$

Indeed, the university as an institution valuing citizenship and social responsibility seems to be officially recognised now only when its rooms are revealed to be the site of potential occupation by its own "workers." 24 The protest for an alternative to the sacrifices demanded by economic "reality" is politically denigrated as at best utopian and at worst insane. Here the student protests in relation to which interpretations of Iphigenia in the late 1960s may be contextualised still pose the question of their "contemporary" meaning today, not least in terms of the responsibilities of university managements for the material conditions of and for an engagement with such questions of cultural memory. ${ }^{25}$ This is not simply a matter of how the past becomes intelligible in terms of the present (hermeneutics); but of how such cultural memory is itself a medium in which the present may appear in the future (praxis). Even if not revolutionary, the question of "alternative" voices that are not simply denigrated as "insane" - as if ("without reason") they were to be sacrificed to the law (in the name of "necessity") - concerns what it is of the politically and culturally repressed that returns with the example of Iphigenia.

\subsection{Counter-Violence}

In the run up to the founding of the Green Party in West Germany, Beuys published an "Appeal for an Alternative," in the Frankfurter Rundschau (23 December 1978), in which he noted, with respect to "the aim $[\ldots]$ to break through into a new social future $[\ldots]$ ": "In response to the question 'What can we do?' we have to explore the question 'what must we think?'" (cit. Beckman, "Causes" 105). This question is at the heart of what Beuys means when he calls his work "social sculpture," in an understanding of art as a material expression of the life of forms, as themselves modes of thinking. ${ }^{26}$

The relation between doing and thinking, between praxis and theory (or, even, between performance and philosophy) - as variations on the vexed question of the relation between interpretation and the world was addressed by Adorno, reflecting specifically on the politics of the extra-parliamentary opposition (the self-proclaimed "Iphigenists of the world"), in an essay titled, "Marginalia to Theory and Praxis" (1969). ${ }^{27}$ There Adorno mordantly identifies, in the student activism of the 1960s, "a sure sign" of "the petit bourgeois disdain for all spirit," characteristic of the "opiate of collectivity":

the question "what is to be done?" as an automatic reflex to every critical thought before it is fully expressed, let alone comprehended. Nowhere is the obscurantism of the latest hostility to theory so flagrant. It recalls the gesture of someone demanding your papers. (276)

Rejecting the "direct action" of student protest (not least as a curtailment of his academic freedom to teach, alongside the potential consequences of institutional "reforms" by university managements ${ }^{28}$ ), Adorno notes:

What imposes itself straightaway is the bourgeois supremacy of means over ends, that spirit actionists are, at least programmatically, opposed to. The university's technocratic reforms they, perhaps even bona fide, 
want to avert, are not even the retaliation to the protest. The protest promotes the reforms all on its own. Academic freedom is degraded into customer service and must submit to inspections. (274) 29

The contemporary resonance of these remarks concerning the potential consequences of praxis (and more generally the sense that ends and means are not, least of all "technocratically," separable) is curiously deformed by the suggestion that the demonstrators are as responsible for the behaviour of the bureaucracy (and, perhaps, even the police) as for their own. University managements, after all, are hardly concerned with students' actual academic interests - increasingly alienated today as the supposed "consumers" of a choice of "student experience" whilst implementing "reform" policies that serve only to promote the continuing marketisation of higher education. ${ }^{30}$

In a strange twist to questions of historical time and artistic form, conservative critics like to invoke " 1968 " to denounce the consequences of an era in which the Student Movement was part of a significant, extraparliamentary political opposition. In contrast to such demonising of "Iphigenists," Peter Handke (in his testimony to Beuys' performance) evoked the question of the utopian event (as, perhaps, performance in theory and philosophy in practice). These relations are glimpsed in the potential of a "distance" that remains political as it engages with the antinomies that appear to constitute it; above all, with respect to that "alternative" to state violence which begins, in Ulrike Meinhof's phrase, as "counter-violence" and is then identified with "terrorism" (Meinhof, "Protest" 242). Handke writes, in terms that still resonate today:

The demand for spectator-participation becomes hypocritical and infamous in the theatre, when by participation is understood, not the cool clear reflection of a distanced and exerted audience, but the mechanistic activism of merely physical, unaware reflexes. It has to be said clearly: the more distant and hermetic the events on the stage, the more possible it becomes for the spectator to apply them concretely to his own situation but if everything is presented to him as a finished product with defined content, then he is deprived of the most important effort of making the concrete connection. (cit. Tisdall, Joseph Beuys 182) 31 $^{31}$

To preach an ideal is to attempt to extract practice from its participation in the antinomies of its own thought (or "philosophy"), from a distance the interpretation of which (as of any "freedom" of action) is critical in being "concrete" (understood in terms of its mediation and contradictions). Here we might ask: what is it of performance that finds its mode of existence in the critical distance - or potential - theorised by philosophy in an example of artistic form? What is it of the past that has yet to occur in its future? What is still to be understood in the example, in the event, of Iphigenia today?

\section{Notes}

There are two kinds of footnote to this chapter: one for references and one that evidences the failure to include material in a synoptic form (in which these parts would find their expression in relation to the whole). However, it is perhaps this failure that is the real lesson of the material, especially in attempting to address the ongoing war on claims for (particular) autonomy against a (universal) commodification in the context of current higher education policies. As an example, therefore, these notes could be read separately, returned to after the main text.

1. Adorno, "On the Classicism of Goethe's Iphigenia," 157. A fragmentary summary of the lecture can also be found in Adorno's preliminary outline, published in Volume VI of the Frankfurter Adorno Blätter (Tiedemann 118-119).

2. For a historical review of German reception of Goethe's play, see Hall, Adventures with Iphigenia in Tauris and Wagner, Critical Approaches to Goethe's Classical Dramas.

3. One could compare this with Adorno's reading of Brecht, where "the artistic principle of simplification not only purged politics of the illusory distinctions projected by subjective reflection into social objectivity, as Brecht intended, but it also falsified the very objectivity which didactic drama laboured to distil" (Adorno, "Commitment" 309). While Adorno cautions that Brecht's political efficacy consists in "preaching to the converted," he also cautions against this same view where it is a consequence of separating the political from the artistic, as if the historical tensions of the one could be isolated from those of the latter (310).

4. This might be the very scenario within which Jacques Rancière's essay on the "emancipated spectator" has gained such widespread popularity.

5. At the end of the Cold War, "human rights" were declared to constitute the "end" of history (as if the abstract had indeed become concrete, or as if a "humane law" had come to power). This claim has since been subsumed by the legitimation of continual imperialist wars as "humanitarian interventions." The sophistry (or perhaps cynicism) offered by military code names for such operations - like the presciently ambivalent "Enduring Freedom" in Afghanistan - could not be thought up by even the most subtle dialectician (pace Adorno, "Warning: not to be misused" in Minima Moralia 244-247).

6. This is the essence of Hannah Arendt's analysis of the Eichmann trial (which we could perhaps re-name "Kant in Jerusalem"), addressing the totalitarian formation of conscience by law within a criminal state (pace Arendt, Eichmann 136-137).

7. Peter Szondi made a similar observation on the occasion of Adorno's Goethe lecture in Berlin, referring to those protesters "who go around quoting Mao's 
sayings in much the same way that their grandfathers quoted the sayings of the Weimar 'Greats'" (cited in Müller-Doohm, Adorno 455). The tensions of this situation are given exemplary artistic form in Godard's 1967 film, La Chinoise. 8. In Barnett's account of Fassbinder's version:

The lack of development of Thoas through humanistic education and the unremitting nature of his cruelty is felt at the play's conclusion. Arkas tries to remember the final words of Goethe's play, in which Thoas speaks of his admiration for Orestes, who is supposed to depart with his sister Iphigenia, and bids 'farewell' to the Greeks. But their reconciled ending is not permitted in Fassbinder's version, and Arkas, Orestes, [...] Pylades and Iphigenia simultaneously deliver despondent monologues before the lights go out. (Rainer Werner Fassbinder 87-88).

9. Aristotle gives a plot summary of Euripides' play in the Poetics (Kassel, Aristotle's Ars Poetica 1455b).

10. The construction of the barbarian as a founding myth of the classical Greek legacy of, for instance, "democratic freedom" is the subject of Hall's Inventing the Barbarian; and, with respect to Goethe's Iphigenia specifically, of Geyer-Ryan's "Prefiguring Racism in Goethe's Iphigenia auf Tauris."

11. Peymann had seen Beuys' installation at Documenta IV (in 1968) and, "unable to get the image out of his mind," phoned Beuys to invite him to make a stage design at Frankfurt - which Beuys, however, declined. "The conversation was effectively over when Peymann said that it was for Iphigenia. 'But tion was effectively over when Peyman exclaimed. 'Have you already got someone to play the main role?' Although there had been a long standing commitment to Ulrike Laurence, with Beuys' offer to perform everything changed" (Koberg, Claus Peymann 97).

12. In "looking at the photographs [by Ute Klophaus] from the show [in this case, the 1976 installation Show Your Wound], Beuys had the idea of mounting such negatives as 'radiographs' on a sheet of opalescent glass" (Schellmann, Forty 38). Presented as a multiple "edition," this image - as a "radiograph" Forty 38). Presented as a multiple "edition," this image - as a "radiograph" of the perfor appears to refer to. A similar Andronicus photographs in 1985 (44-45), consigning Abisag Tulimann's photographs of the event to the status of documentation. Tüllmann's images are, however, used by Eva Beuys in her book, Joseph Beuys Iphigenie, which accompanied the 2011 exhibition Joseph Beuys: Ich (Ich Selbst Die Iphigenie), with its own catalogue edited by Jörg Schellmann (Munich: Schellmann Art, 2011). In the photo credits in the catalogue for the subsequent showing of this exhibithe Galerie Thaddaeus Ropac, Paris, Tüllmann's images are described as being from a rehearsal (Schellmann, Beuys Iphigenie 108). Needless to say, these images can be found on the Internet (searching for "Beuys Iphigenie").

13. The ambiguities of the German Bild - meaning both picture and image (and, indeed, metaphor) - introduce a further level of complication into this discussion.

14. "In der Erinnerung scheint es einem eingebrannt in das eigene Leben, ein Bild das in einem Nillen, an solchen Bilder But einem selber zu arbeiten an" (Handke, "experimenta 3" 105).
15. Robert Hullot-Kentor's translation is slightly different:

By the transposition of impulses into artworks, which make them their own by virtue of their integration, these impulses remain the plenipotentiary in the aesthetic continuum of extra-aesthetic nature yet are no longer incarnate as its afterimage. This ambivalence is registered by every genuine aesthetic experience, and incomparably so in Kant's description of the feeling of the sublime as a trembling between nature and freedom. (Adorno, Aesthetic Theory 113).

16. The banners were, however, pulled down by other students present (Tiedemann, Frankfurter Adorno Blätter 123).

17. This is not, however, the impression given in Kraushaar's "chronology" of the Frankfurt School and the Student Movement, op cit., Frankfurter Schule vol. 1 (Chronik), 264-265.

18. Adorno "in fact" later spent an afternoon in discussion with students in Berlin before returning to Frankfurt, about which his only regret was that he had to leave early. This comes from Adorno's letter to Helge Pross [13.06.67], in which he also describes the Berlin events as "the Berlin Happening" (Kraushaar, Frankfurter Schule vol. 2 (Documents), 271).

19. "Closure for its own sake," Adorno observes in Aesthetic Theory, "independent of truth content and what this closure is predicated on, is a category that in fact deserves the ominous charge of formalism" (159).

20. Adorno's lecture had been commissioned by the Goethe Society the previous year and had initially been called "Against crudeness" [Gegen das Rohe] (rather than "On Goethe's Classicism"), which Tiedemann explicitly makes a key to his own reading of the subsequent "events" of its reception by evoking the 1930s (Tiedemann, Frankfurter Adorno Blätter 124-125).

21. The agitation of the Springer Press was also widely regarded as contributing to the charged atmosphere in which an assassination attempt was made on Rudi Dutschke by a neo-Nazi, Josef Bachmann, in April 1968 (Müller-Doohm, Adorno 459; Wiggershaus, Frankfurt School 626).

22. That the violence associated with a "state of emergency" is currently masked by legislation concerning "deficit reduction" does not make it any less victimless, punishing the poorest in society to protect the privileges of the richest. The anti-democratic premise of such policies is perhaps most explicit with the "troika" dictatorships in Greece and Portugal. What political party, for instance, could fight an election with a policy advocating over 25 per cent unemployment, rising to over 60 per cent amongst the under $25 \mathrm{~s}$ ? A recent letter to The Guardian (27 September 2013) makes this appeal on behalf of Greek universities, for instance:

The University of Athens, the Aristotle University of Thessaloniki and the Athens Polytechnic have been forced to halt all activities as a result of Greek ministry of education proposals to suspend unilaterally 1,655 university administrative workers. The impact on teaching, research, clinical work and international collaboration is unparalleled and the threat to higher education in Greece as a result of stringently imposed $\mathrm{EU}$ austerity measures is a cause of great concern far beyond Greece's shores. As academics, university workers, students and others, we call on 
the EU and the Greek government to protect the status and staff of Greek universities, to ensure that they remain able to engage in education and research and to recognise that these institutions are more important now than ever. They are and must remain beacons of critical thinking in a Europe whose social structures are being eroded by massive cutbacks and Europe whose social structures are shadow of far-right extremism looms. (Adamson et al.)

23. The Daily Telegraph, for instance, reported on the results of "PA Consulting Group's annual survey into higher education" under the headline "University leaders fear a third will go bankrupt": "The survey says that several of the university leaders who were questioned predicted up to 30 higher education institutions could become 'unviable'," in a situation of "increased competition among universities for students" (cit. in Anonymous, Daily Telegraph). Indeed, according to the Times Higher Education, the UCAS End of Cycle Report for 2012-2013 notes that "while higher tariff institutions [those expecting A-level grades of $A A B$ or abovel expanded by 10 per cent this year, taking on A-level grades of $\mathrm{AAB}$ or above expanded by 10 per cent this year, taking on another 10,000 students, about 20 per cent of universities that suffered fall-
ing recruitment in 2012-13 experienced a second year of declining student numbers" (Grove, "Student recruitment" 7).

24. The increasing attempt by university managements to criminalise such protest is analysed by the campaigning organisation "Defend the Right to Protest," whose website can be accessed at: www.defendtherightotprotest. org. See also Cooper et al.

25. To acknowledge here but one example of support for current student protests in the UK, the following letter was published in The Guardian (22 June 2013):

Students at Warwick are occupying the university's council chamber in protest against further marketisation and managerialism in higher education... The university is now threatening legal or disciplinary action, and it would appear it is embarrassed by the prospect of the occupation being visible during open days this weekend. What Warwick University managers should be embarrassed by is the $£, 42,000$ pay rise awarded to managers should be embarrassed in lobbying for fee rises and other measures which have attacked the public and ing actions of students at Warwick are a accessible nature of education. The actions of students at Warwick are a legitimate response to they et al.) See also Bailey and Freedman

26. As Beuys writes (amplifying the relation between his terms, "thinking forms," "spoken forms," and "social sculpture"): "My objects are to be seen as stimulants for the transformation of the idea of sculpture, or of art in general. They should provoke thoughts about what sculpture can be and general. They should prove materials how the concept of sculpting can be extended to the invisible materials used by everyone" (cit. Tisdall, Joseph Beuys 6). Beuys' sense of the work of art comes to include the founding of an anti-political party and involvement in projects of "direct democracy."

27. The question of theory and praxis concerns the possibility - or otherwise of a revolutionary situation, which was not the least of what was in dispute between the student movement and Adorno (for whom the term "regressive" seemed more applicable). Unpublished in the original (1969) edition of Adorno's Critical Models, the essay was included in its reprinting as part of the Complete Writings in 1977. By the end of that fateful year in Germany, the figure of Iphigenia in performance was linked to the memory of Ulrike Meinhof in Claus Peymann's production in Stuttgart, this time with Kirsten Dene in the title role (while a revival of Fassbinder's play at the TAT, however, was poorly received, seeming to have become "outdated").

28. This is at the heart of his letters to Marcuse concerning the occupation of the Institute for Social Research in January 1969, the subsequent police intervention, and trial of Hans-Jürgen Krall.

29. Stefan Collini observes of the "fallacy of uniformly measurable performance" underpinning current HE policy to make universities "conform to market ideology":

The logic of punitive quantification is to reduce all activity to a common managerial metric. The activities of thinking and understanding are inherently resistant to being adequately characterised in this way. This is part of the explanation for the pervasive sense of malaise, stress, and disenchantment within British universities. ("Sold Out")

As a critic of the mediation between art and audience, not least by academia, Claire Bishop remarks of her own experience ("when working at Warwick university") of two forms of such "measurement," the Research Assessment Exercise and the Quality Assessment Audit, that: "The question of criteria of judgement in relation to academic activities had become crushingly remote from the motivations that first led me into this profession. When I encountered artists speaking of education in creative and liberatory terms, it seemed perplexing, if not wilfully misguided: for me, the university was becoming one of the most bureaucratic and stiflingly uncreative environments I had ever encountered" (Bishop, Artificial Hells 245).

30. This neoliberal project has been dubbed a "gamble" by Andrew McGettigan, who observes that:

The move to a generalised fee and loan regime is part of a more profound transformation of higher education and the public sector in general. The agenda is to create a lightly regulated market of a diverse range of private companies with direct public funding to institutions diluted to homeopathic levels. An experiment is being conducted on English universities; one that is not controlled and that in the absence of any compelling evidence for change threatens an internationally admired and efficient system. (McGettigan, Great University Gamble 2)

While the attempt to privatise the Student Loan Book offers the most obvious index of this policy, its corrosive effects in the understanding of culture and public space demonstrates the "freedom" of capital to define politics in its own terms.

31. On the historical, political-economic degradation of the idea of "participation" in art, specifically as it relates to Beuys, see Bishop, Artificial Hells 243-245. 